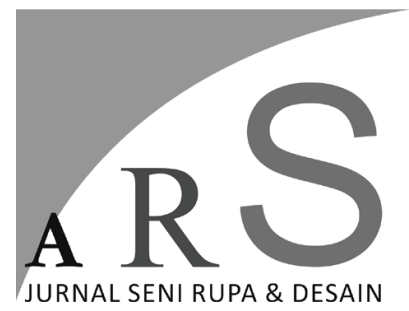

Volume 21 Nomor 3,

Desember 2018

\section{VISUAL THIEF, SUREALISME DALAM ART BOOK KARYA RESATIO ADI PUTRA}

\author{
Novia Nur Kartikasari \\ Pengkajian Seni Pertunjukan dan Seni Rupa UGM \\ Jl. Teknika Utara, Pogung, Mlati, Sleman, Yogyakarta, 55281 \\ E-mail: vikopi.vi@gmail.com
}

\begin{abstract}
ABSTRAK
Visual Thief merupakan sebuah artbook (disebut Art Book) kumpulan kolase karya Resatio Adi Putra, hanya dicetak sejumlah 200 eksemplar. Beberapa karya didalamnya pernah diikutsertakan dalam pameran, serta terlibat dalam beberapa projek tertentu. Resatio Adi Putra menyatakan bahwa karyanya bergenre surealis, selain kemunculan objek rubah sebagai pengganti konsep pencurian yang diusung Resatio dalam Visual Thief, kecenderungan Resatio memakai objek perempuan dalam karyanya memungkinkan munculnya sebuah metafora. Menggunakan teori surealisme yang dikemukakan oleh Andre Breton. Analisis karya Resatio dalam Visual Thief, dari detail setiap objek hingga fragmentasi yang tersusun menjadi berbagai macam komposisi menampakan beberapa ciri surealisme yaitu munculnya kejanggalan, penampakan mimpi, mengandung erotisme serta teror, namun karyanya tidak dapat sepenuhnya dikatakan bergenre surealis (less surrealism), karena ada salah satu unsur yang tidak muncul yaitu otomatisme, yang mensejajarkan fragmen dari dorongan alam nirsadar.
\end{abstract}

Kata Kunci: Visual Thief, Resatio Adi Putra, kolase, surealisme

\title{
ABSTRACT
}

Visual Thief is the artbook collection of collage art works (called Art Book) of Resatio Adi Putra printed in only 200 copies. Some of the art works from this collection were part of exhibitions are were involved in certain projects. Resatio Adi Putra claimed that his works can be identified as surrealism, in addition to displaying a fox as an object with the potential existing symbolism that indicates the thief as the holder of collection, Resatio's tendency of using woman as object in Visual Thief enables his works to produce a strong sense of metaphors. Includes the theory of surrealism introduced by Andre Breton. The analysis of Resatio's Visual Thief, including the detail of each object and composing fragmentations into various forms of composition, have managed to project identifiable characteristics of surrealism, namely the emerge of flaws, the appearance of dream, as well as dose eroticism and terror. However, it may be argued that Resatio's works do not represent a pure surrealism type of art, as they lack one essential aspect namely automatism, which aligns the fragments of unconsciousness encouragement.

Keywords: Visual Thief, Resatio Adi Putra, collage, surrealism 


\section{Pendahuluan}

Berkarya adalah bercerita tanpa kata-kata, tentang berbagai hal dari sosok seniman sendiri atau tentang bermacam hal disekitarnya. Karya seni rupa sangat erat kaitannya dengan industri kreatif, yang makin diminati dan didominasi oleh kalangan anak muda, sebagai kegiatan positif yang menghasilkan profit. Sebuah barang pakai yang berasal dari karya seni cenderung memiliki nilai plus dimata pemakai, baik yang memang memiliki ketertarikan lebih di dunia kesenirupaan maupun penyuka belanja yang suka mengeksplore barang-barang unik dan ingin sesuatu yang berbeda dari kebanyakan orang.

Pembeli barang atau produk yang dibuat para seniman tidak melulu orang yang paham betul mengenai sebuah karya seni ataupun orangorang yang berkecimpung di dunia kesenirupaan, mereka menyukai karya bukan hanya karena komposisi objek atau berbagai objek di dalamnya, tetapi bisa juga karena tone warna atau packaging dari karya, jika sesuai dengan selera ataupun kebiasaan keseharian mereka tentu tidak berkeberatang dengan minimnya pemahaman akan makna dibalik karya yang tersemat dalam produk kesenian tersebut.

Salah satu seniman yang mengemas karyanya dengan apik ke dalam bentuk berbeda adalah Resatio Adi Putra, seniman dengan spesialisasi teknik kolase yang telah aktif berkarya sejak tahun 2005, namun baru serius menekuni industri seni dan kreatif dengan karya kolasenya sejak tahun 2008. Memutuskan untuk menekuni teknik kolase setelah melakukan beberapa eksperimen dengan teknik lain, kemudian merasa bahwa kolaselah yang paling sesuai untuk merepresentasikan pikiran dan perasaan yang ingin diungkapkan pada karyanya. Karya kolase yang dibuat oleh Resatio menggunakan kombinasi teknik manual dan digital, yang secara garis besar merupakan kombinasi dari berbagai objek seperti manusia, binatang, tanaman dan still life (benda mati). Nuansa gothic kental terasa dalam setiap karya kolase Resatio yang beraliran surealis.

Resatio mengemas karyanya dalam berbagai bentuk lain seperti asesoris dengan merk Kala Jewerly, dicetak pada kaos, kartu pos yang dilengkapi dengan puisi. Karyanya juga muncul dalam bentuk desain untuk beberapa majalah serta sampul buku. Sedangkan artbook kumpulan karya Resatio merupakan salah satu yang dibuatnya secara kontinu dalam beberapa seri, bukan seperti asesoris yang bisa dipakai namun sangat diminati dan banyak mendapat apresiasi. Karya yang dimasukan kedalam artbook tentunya bukan merupakan karya asli karena dicetak dalam jumlah yang lebih banyak (meski terbatas), namun tidak bisa dikatakan bahwa nilai dari karya tersebut berkurang, ataupun mengurangi ketertarikan para apresiator meski karya surealis cenderung menimbulkan ketidak nyamanan atas bentuk-bentuk yang janggal.

Salah satu artbook resatio yang akan dibahas dalamtulisan iniberjudulVisualThief, merupakan yang kedua setelah Reconstructing Collage (2013) dan ketiga berjudul Your Nightmare yang dicetak pada tahun 2016. Visual Thief dicetak dalam jumlah terbatas (200 copy) pada tahun 2014 berisi 52 halaman yang memuat 45 karya kolase Resatio, beberapa karya pernah diikutsertakan dalam pameran seni rupa. Artbook "Visual Thief" berukuran A5 $(15 \times 21 \mathrm{~cm})$, sampul depan dan belakang dicetak dengan kertas coronado 270 gsm (gram per squaremeter), sedangkan isi dicetak dengan menggunakan kertas hvs 100 gsm, dijilid secara manual oleh Resatio sendiri dengan teknik japanese book binding. Resatio beranggapan bahwa teknik kolase merupakan sebuah penulisan ulang sejarah, sebuah proses mendekonstruksi dan merekonstruksi.

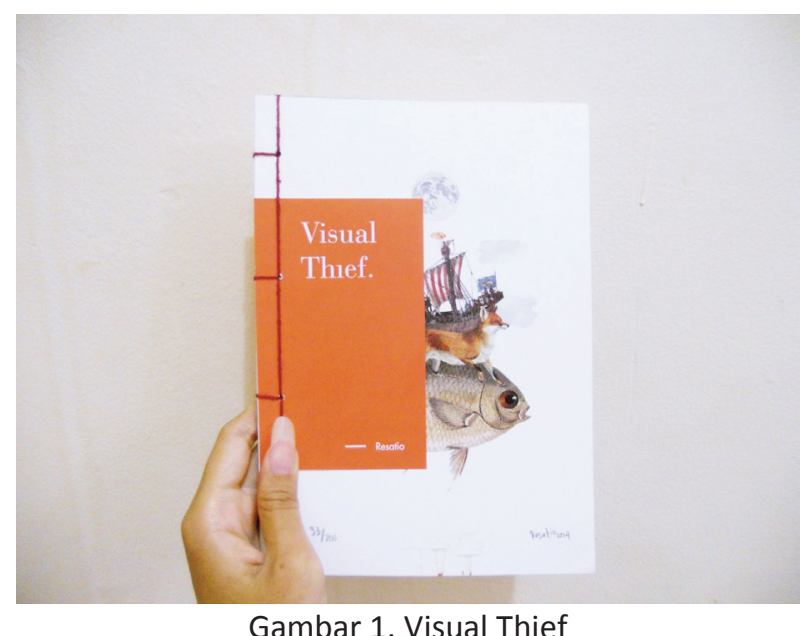

(Foto oleh: Novia Nur Kartikasari, 2015)

Visual thief menjadi menarik karena konsep awalnya mengenai 'pencurian' seperti yang 
dijadikan judul artbook. Visual yang dimaksud merupakan hal atau benda kasat mata seperti gambar, foto atau tulisan, dan lain-lain, yang menjadi objek untuk dicuri. Resatio, sebagai seniman kolase mengibaratkan dirinya sebagai pelaku, yaitu pencuri berbagai objek kasat mata tersebut, untuk dijadikan karya utuh hasil ciptaannya. Rubah ( $f o x$ ) merupakan analogi yang dijadikan resatio sebagai sosok pencuri, yang kemudian dikombinasikan dengan objek manusia, binatang lain, bunga dan tumbuhtumbuhan, tulang belulang manusia ataupun binatang, bola mata, alatt transportasi, jam, bulan, dan berbagai objek lain. Kombinasi yang berbeda-beda menjadi sebuah cara menyampaikan secara implisit metafora yang sebenarnya ingin disampaikan oleh seniman dalam gaya surealistiknya.

Kemudian apakah yang menjadikan karya resatio dalam Visual Thief dapat disebut surealistik, tentu dapat dijelaskan melalui penjelasan konsep yang mendasari terbentuknya artbook tersebut, hingga dapat dianalisis ciriciri kesurealisan dalam karya Resatio Adi Putra. Kajian mengenai surealisme sendiri sangatlah luas, tidak hanya pada karya rupa namun juga pertunjukan seperti seni ataupun teater serta beberapa bidang kajian lain. Kolase juga bukan sebuah proses yang hanya ditemukan dalam bidang seni rupa tapi juga sastra maupun musik.

Buku yang mengupas tentang surealisme juga ditulis oleh Keith Aspley, berjudul "Historical Dictionary of Surrealism", berisi tentang surealisme yang diterapkan di berbagai bidang, seperti sastra, teater, film, seni rupa dan berbagai bidang lain, beserta seniman-seniman yang terlibat dalam berbagai bidang tersebut. Mona Hadler (2011:95) dalam tulisannya yang berjudul "David Hare, Surrealism, and the Comics", dimuat dalam jurnal The Space Between. Berisi tentang sejarah komik yang terbit di Amerika, kemudian tentang Hare, seorang pematung yang mengamati sisi dark humor dari ceritacerita dalam komik sebagai sumber inspirasinya dalam berkarya, hingga muncullah istilah Gothic Surrealism untuk karya-karya yang dibuatnya.

Mary Frances (2009:15-20) melakukan penelitan dengan mengambil kolase sebagai objek kajian, berjudul "Collage and Cut-Ups the
Art of Re-Arrangement", menjelaskan mengenai serba-serbi kolase yang pada dasarnya merupakan sebuah konstruksi dan penyusunan ulang, fokus pada kolase yang diterapkan pada karya sastra seperti puisi, maka Francer menyusun kembali tulisan-tulisan yang ada untuk membuat karya baru.

Berbicara mengenai surealisme erat kaitannya dengan kolase karena tidak lepas dari menyoal fragmen-fragmen yang menyatu dalam karya rupa. Kolase merupakan komposisi artistik yang dibuat dari berbagai bahan atau elemen, bisa dari kain, kertas, foto, benda bekas ataupun serpihan kayu, yang di dalamnya meliputi kegiatan memotong dan menempel, selain itu bisa dikombinasikan dengan goresan manual menggunakan pensil, spidol, dan cat.

Teknik kolase pada dasarnya bukan teknik yang rumit, seperti yang dijelaskan oleh Grant Pooke dan Diana Newall (2008:219)

"Collage from the French verb 'to stick
or glue,, used to refer to the practice
invented by Picasso of sticking fragments
of paper, board, flyers, etc. to the surface
of their cubist compositions. In addition
to changing the nature and texture of the
painted surface, collage symbolised the
introduction of everyday objects into the
process of art making"

Intinya adalah tentang komposisi yang berasal dari penggabungan benda-benda tidakk utuh atau potongan, sedangkan Ernst mendefinisikan kolase sebagai "something like the alchemy of the visual image" (Warlick, 2001:1) (sesuatu seperti alkimia dari citra visual). Ernst menggunakan kolase sebagai sebuah metode dengan cara memotong dan merakit beberapa gambar temuan untuk dijadikan sebagai satu gambar utuh. Alchemy merupakan sebuah analogi yang digunakan untuk menyebut proses kerjanya dalam membuat karya seni, tentu bagi pecinta novel fiksi bergenre fantasi sudah tidak asing lagi dengan istilah alkimia yang cenderung dekat dengan kisah-kisah para penyihir.

Kolase menjadi sebuah teknik yang digemari dari masa ke masa, beberapa seniman menggunakan karya kolase sebagai metode yang 
dominan digunakan dalam membuat karya untuk dipamerkan. Salah satu contoh pameran kolase yang pernah diadakan pada tahun 1978, yaitu 'The Surrealist Collage exhibition' (Aspley, 2010: xxiv) di Paris, merupakan pameran yang menyuguhkan karya kolase sekaligus mengenalkan pentingnya karya seni bergaya surealis pada masanya. Seorang seniman yang mencoba bereksperimen saat awal kemunculan teknik kolase adalah Pablo Picasso, yang secara bertahap mengembangkan bentuk-bentuk kubisme dengan menempelkan sobekan-sobekan kertas (papiers collés) (Keith Aspley, 2010; 81) pada lukisannya.

Kolase tidak melulu dibuat dalam bentuk dua dimensi tetapi juga tiga dimensi, seperti yang dijelaskan seperti berikut:

\section{"Collage abandons the illusion of depth we associate with single-point per-spective. This is not to imply that collage never takes three-dimensional forms. In fact, three-dimensional collage, as weve seen, is routinely referred to as "as-semblage". (Fiddler, 2002:21)}

Kolase memungkinkan adanya penggabungan fragmen-fragmen yang akan menciptakan bentuk baru dari bentuk yang telah ada sebelumnya, hingga menciptakan komposisi yang ganjil. Hannah Höch (1889-1978), merupakan salah satu seniman Dada dan surealis yang bersungguh-sungguh menekuni teknik kolase. Seniman wanita yang berasal dari Jerman ini menggunakan teknik kolase dalam berkarya, menggabungkan berbagai potongan gambar objek bagian tubuh manusia, serta potongan tulisan-tulisan dari berbagai sumber, tidak dijadikan sebuah kalimat utuh, hanya menjadi bagian dari karya visual. Salah satu karyanya yaitu 'Cut with the Kitchen Knife through the Beer-Belly of the Wimar Republic', dibuat pada tahun 1919 yaitu selama dan sesudah perang dunia I yang merupakan karya bergaya Dada, penggabungan dari berbagai gambar objek dan potongan tulisan, merupakan karya seni yang bearoma politis.

Gerakan surealisme berawal pada abad 20-an di Paris, diprakarsai oleh André Breton, tepatnya pada tahun 1924 , kemudian diikuti oleh beberapa seniman seperti Max Ernst, Salvador Dali, dan banyak lagi seniman dari berbagai bidang lain. Surealisme awalnya selalu dikaitkan dengan wacana psikoanalisis yang dikemukakan oleh Sigmund Freud, mengenai hal-hal yang irrasional, absurd dan tidak logis. Freud selalu memisahkan antara alam sadar dan alam ketidaksadaran (unconsciousness), di antaranya terdapat 'sensor' yang menjembatani keduanya, batas tersebut lah yang sesungguhnya ingin ditembus oleh Breton dan kawan-kawan dalam gerakan Surealisme.

Kata 'sureal' (surreal) memiliki arti "more than real" (lebih dari nyata) atau "better than real" (lebih baik dari kenyataan). (Mc. Neese, 2006:12) Surreal berasal dari dua kata yaitu 'sur' yang berarti 'di atas' dan 'real' yang berarti 'nyata', jika diartikan secara sederhana, segala sesuatu yang sureal merupakan sesuatu yang berasal di luar kesadaran (unconsciousness). Breton menjadi pemimpin gerakan surealisme yang merupakan eksplorasi alam luar sadar, interpretasi mimpi, dan penulisan otomatis yang merupakan ketertarikan para surealis. (Hofmann, 2001:16) Breton (2009; 943) memberikan definisi tentang surealisme yaitu:

"Surrealism is based on the belief in
the superior reality of certain forms of
association heretofore neglected, in the
omnipotence of dreams, in the undirected
play of thought... I believe in the future
resolution of the states of dream and
reality, in appearance so contradictory, in
a sort of absolute reality, or surreality".

Breton (2009; vi) menyatakan bahwa menjadi surealis merupakan suatu hal yang disebabkan oleh bisikan taksadar dari maksud rasional seniman (being a Surrealist was something caused by unconscious motives quite aside from the artist's rational intentions). Kehadiran motif alam luar sadar adalah bentuk otomatisme, berkaitan dengan kondisi psikis seseorang, masih berkaitan dengan wacana psikoanalisis yang dijelaskan oleh Freud (1960:26) sebagai berikut: 
"SURREALISM, n. Psychic automatism in its pure state, by which one proposes to express-verbally, by means of the written word, or in any other manner-the actual functioning of thought. Dictated by thought, in the absence of any control exercised by reason, exempt from any aesthetic or moral concern".

Beberapa karya yang terdapat dalam Visual Thief yang akan dianalisis dalam tulisan ini adalah: Notes from a Fox, Dromomania, Study of YKHA AMELZ's Desember, Study of Mahendra Nazar's Inspection II: Mother Earth, An Odd Voyage, Rejuvenate.

\section{Pembahasan}

\section{Visual Thief dan Resatio Adi Putra}

Resatio menyatakan bahwa karyanya bergaya surealis, kemudian menjelaskan bahwa karyanya merupakan potongan dari dua hal yaitu "keanehan" dan suatu elemen yang retrofuturistik, dan itu menjelaskan tentang mengapa dia memilih surealisme (Resatio describes his pieces as having both "whimsical" and "retro(futuristic)" elements, and it is clear why) (Cut, Paste \& Collage: Making Art Magic From the Mundane, dari wawancara Resatio di Jakarta Globe).

Bahan-bahan yang dipakai Resatio untuk membuat karya kolase berasal dari berbagai sumber, mulai dari ilustrasi vintage (19001970an), ilustrasi era Victoria (1837-1901), bahkan sampai ilustrasi tahun 1600an, itulah mengapa karya kolase yang dibuatnya selalu bernuansa kelabu, berwarna 'tua', serta tidak menampilkan warna yang mencolok. Selain menggunakan objek dua dimensi berupa gambar yang tercetak di kertas, Resatio juga seringkali memakai found object seperti seperti mainan abal-abal China yang sangat murah, benang, ranting pohon, dan apapun yang tidak sengaja ditemukan dan menarik bagi Resatio (Wawancara kopi keliling (http://kopikeliling.com/artists/resatio-adi-putra. html, diunduh pada 22 Maret 2014), hal tersebut memungkinkan Resatio membuat karya tiga dimensi.

Surealisme tampak khas dengan memunculkan hal-hal yang tidak wajar dan selalu menimbulkan tanda tanya, Resatio juga seringkali menampilkan masa depan yang dimundurkan, atau mungkin digabungkan menjadi satu dimensi yang jelas tidak akan terjadi dalam kehidupan sehari-hari (setidaknya sampai saat ini). Surealisme merupakan pertemuan dari berbagai potongan realitas dan langganan tutur dalam elemen visual maka menghasilkan sebuah sublime point surealistik. (Lash, 2012:162) Kecenderungan yang muncul dalam karya Resatio dapat digunakan untuk memilah ciri-ciri yang kemudian dapat membuat karya tersebut dikategorisasikan sebagai karya beraliran surealis, tentunya dengan berdasar pada karakteristik yang telah ada mengenai batasan-batasan sebuah karya hingga dapat disebut sebagai karya surealistik. Selain mengenai objek, ruang-ruang yang ditampilkan juga merupakan bagian dari komponen karya kolase Resatio, bagaimana sebuah ruang ditampilkan sebagai satu kesatuan dengan berbagai objek yang tadinya merupakan potongan-potongan yang terpisah, kemudian bagaimana karakter objek ditampilkan dapat dibaca sebagai sebuah karakteristik surealis ataupun bukan.

Kemunculan objek manusia dalam karya Resatio, khususnya pada Visual Thief didominasi oleh manusia berjenis kelamin perempuan, adapun keberadaan objek laki-laki hanya terdapat pada beberapa karya yaitu: "Man with Elephant", "Dromomania", "Padri", "Future of History \#7", "Future of History \#8", sedangkan beberapa karya lain yang memunculkan objek manusia bukan perempuan tidak teridentifikasi jenis kelaminnya karena ditampilkan dengan mengenakan full contume.

\section{Surealisme pada Setiap Karya Resatio Adi Putra dalam Visual Thief}

Beberapa karya dianalisis untuk mengetahui dan memetakan ciri-ciri surealisme di dalamnya, dengan memberi perhatian pada detail objek dan relasi antar objek, yaitu:

Notes from a Fox, karya yang sekaligus dijadikan sebagai sampul depan Visual Thief, memiliki tiga jenis objek di dalamnya yaitu binatang yang terdiri dari rubah dan ikan), still life yang terdiri dari kapal, awan berwarna putih semi kelabu, dan bulan, serta jamur, dan manusia-manusia yang terdapat di kapal. 


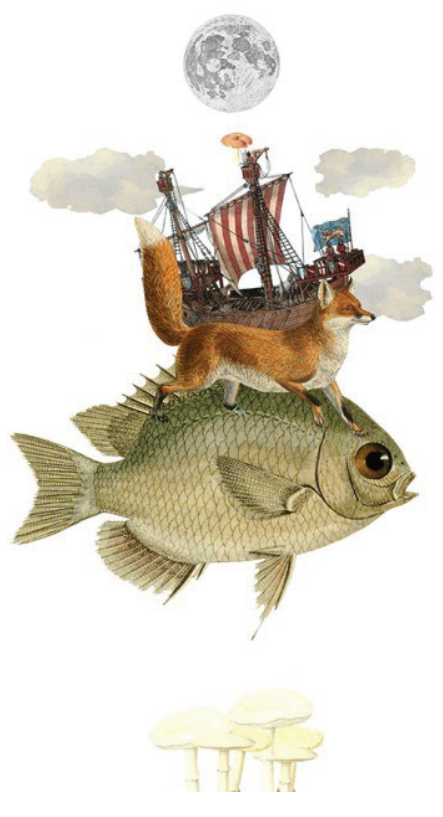

Gambar 2. Notes from a Fox (Foto oleh: Novia Nur Kartikasari, 2015)

Ciri pertama yang dapat dikatakan sebagai aspek surealisme dalam karya ini adalah munculnya kejanggalan, yang dapat dilihat pada proporsi, perbandingan ukuran benda seperti kapal yang biasanya berukuran sangat besar (bisa bermetermeter tingginya) kali ini hanya berukuran sedikit lebih tinggi dari rubah, bahkan rubahpun berukuran lebih kecil daripada ikan, bukan jenis ikan berukuran raksasa seperti paus, hiu atau ikan layar dewasa. Ukuran manusia yang terdapat di atas kapal bahkan jauh lebih kecil lagi, kurang lebih seukuran telapak kaki rubah.

Walaupun tidak terdapat potonganpotongan yang membuat sebuah objek terlihat tidak utuh lagi, karena setiap objek ditampilkan secara utuh atau keseluruhan, namun ciri surealisme dapat dilihat dari penampakan dua binatang yang sewajarnya hidup di dua ekosistem berbeda dapat 'tampil' bersamaan, kalau ruang pada karya tersebut ada di dalam air, maka binatang semacam rubah pasti tidak dapat hidup di dalamnya, begitupun sebaliknya, ikan tidak dapat bertahan lama di udara terbuka. Keadaan tersebut seperti dalam mimpi yang tidak rasional, peristiwa yang awalnya mustahil bisa saja terjadi.

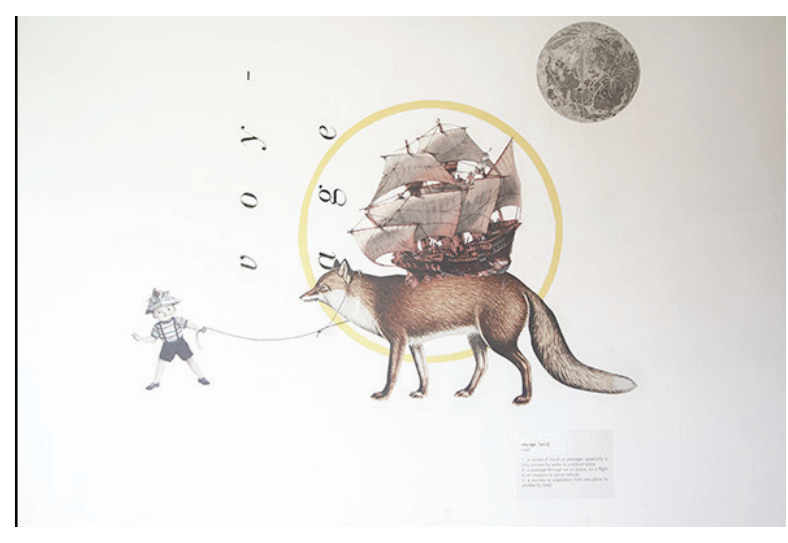

Gambar 3. Dromomania

(Foto oleh: Novia Nur Kartikasari, 2015)

\section{Dromomania}

Merupakan karya mural kolase Resatio Adi Putra, dibuat dengan ukuran yang cukup besar, kurang lebih setinggi ukuran rata-rata manusia (proses singkat pembuatan karya dapat dilihat di https://www.youtube.com/ watch?v=S65rL4oZ83o). Objek yang terdapat di dalamnya terdiri dari, manusia dalam sosok anak laki-laki dengan topi yang tampaknya terbuat dari kertas koran yang dilipat, rubah, kapal layar lengkap dengan anak buah kapalnya, bulan, tulisan 'voy-age', bulan, tali yang mengikat leher rubah dengan longgar, dan lingkaran berwarna kuning yang menjadi background dari semua objek. Penampakan objek dalam karya yang paling menonjol adalah rubah dengan ukuran yang sangat besar, dilihat dari perbandingan ukuran bocah (yang terlalu kecil) yang seolaholah menggembalanya, dengan tali yang sedikit ditarik agar rubah menurut entah akan diajak kemana, sedangkan rubah bukanlah binatang yang sewajarnya dijadikan peliharaan, tidak pula gampang dijinakkan. Penggabungan objek rubah dengan kapal juga menunjukkan sebuah ciri surealisme, dengan adanya asosiasi antara dua elemen yang tidak memiliki keterkaitan.

\section{Study of YKHA AMELZ's Desember}

Berlatar belakang warna hitam pekat, dengan objek manusia, kepala rubah, kapal, tanaman bunga, bola mata yang terletak di tengah kelopak mawar, tangan yang memegang gagang mawar, bulan, serta semacam kabut warna warni yang menutupi sebagian tubuh manusia, yang merupakan seorang perempuan bertelanjang 
kaki, serta sedang dalam posisi seolah akan melompat dari satu tempat ke tempat yang lain.

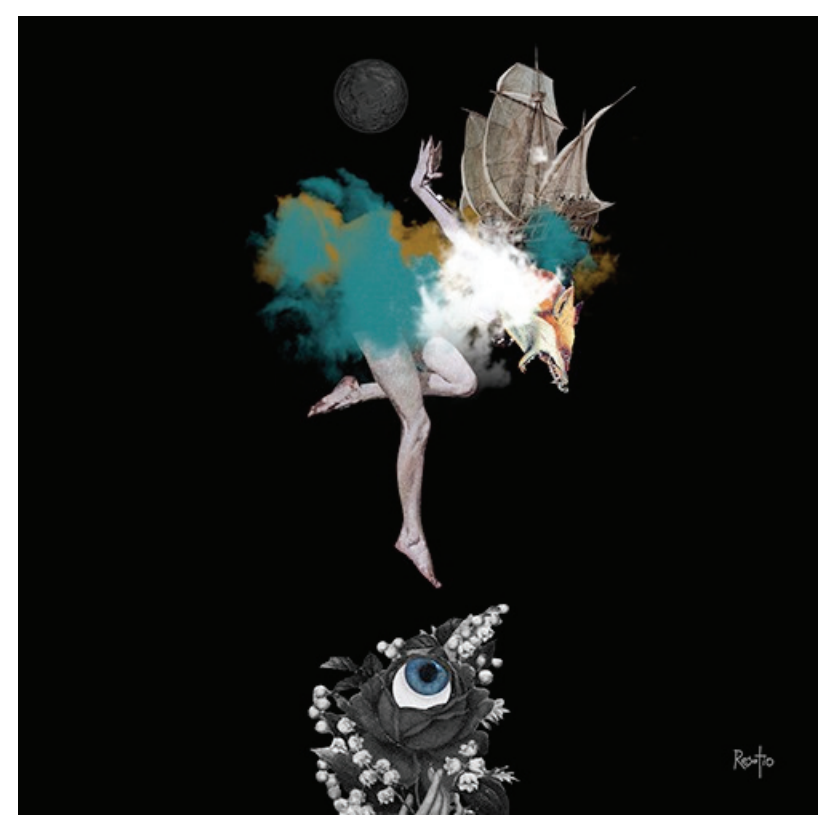

Gambar 4. Study of YKHA AMELZ's Desember (Foto oleh: Novia Nur Kartikasari, 2015)

Munculnya potongan-potongan objek dalam karya ini merupakan bentuk asosiasi bebas yang tidak sewajarnya ditemukan dalam kehidupan sehari hari, bola mata yang tidak berada di kelopak mata seperti yang sewajarnya, manusia berkepala rubah dengan kapal yang menempel di tengkuk seolah menjadi bagian dari tubuh si manusia, serta potongan telapak tangan yang memegang gagang bunga juga merupakan kejanggalan yang sureal. Ciri surealisme juga dimunculkan dengan penampakan erotisme perempuan yang diselubungi kabut berwarna, yang lebih tampak seperti serbuk berwarna yang ditaburkan ke udara.

\section{Study of Mahendra Nazar's Inspection II: Mother Earth}

Masih dengan latar belakang warna hitam pekat, dengan objek manusia, kepala rubah, kucing, jamur, semacam awan atau kabut berwarna warni, bulan, serta beberapa objek berbentuk bulat dan melayang di dekat kepala rubah. Potongan kepala rubah yang menggantikan muka bagian atas si wanita, menampilkan perempuan dalam wujud yang tidak 'utuh' seperti manusia pada umumnya.
Benda-benda absurd seperti bulatan-bulatan yang melayang di sekitar kepala manusia juga tidak dapat dipastikan jenisnya, entah sebuah planet yang berputar pada orbitnya, atau semacam balon-balon gas melayang, diselimuti kabut kabut mistik seperti ilusi, atau sebuah fantasi, salah satu hal yang mencirikan surealisme.

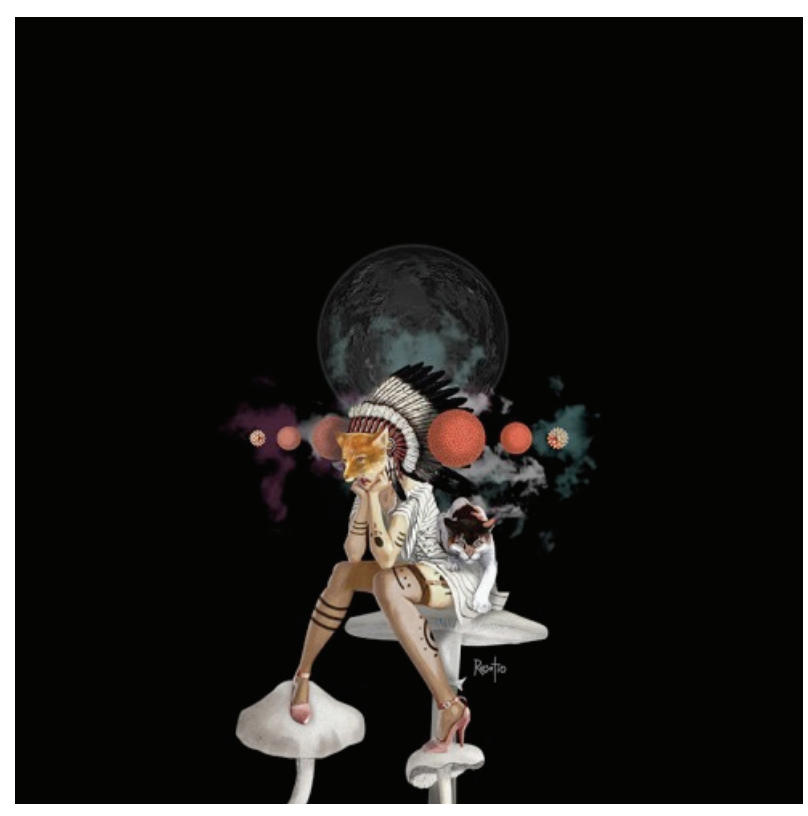

Gambar 5. Study of Mahendra Nazar's Inspection II: Mother Earth

(Foto oleh: Novia Nur Kartikasari, 2015)

Sosok wanita dalam karya kolase ini memiliki tato yang tersebar di sejumlah bagian tubuh, tampak erotis duduk dan berpijak di jamur berukuran raksasa. Jamur merupakan sejenis tumbuhan yang rapuh, setidaknya tidak akan ditemukan jamur yang sanggup menopang berat badan manusia kecuali itu merupakan patung berbentuk jamur, ketika fungsinya disejajarkan dengan kursi, menjadi sebuah metafora yang juga ciri karya surealisme.

\section{An Odd Voyage}

Didominasi warna-warna pastel, dengan beberapa objek di dalamnya yaitu manusia (perempuan), binatang (rubah dan hiu martil), kapal, bulan, jamur, mainan kereta berukuran mini, dan buku. Irasionalitas dapat dilihat pada ukuran rubah yang sangat kecil di atas kepala si wanita, sedangkan rubah yang sesungguhnya setidaknya seukuran kucing, kemudian 
keberadaan hiu martil yang seolah bisa hidup di udara terbuka, atau mungkin sebaliknya, sebenarnya ruang yang tergambar dalam karya ini adalah penampakan bawah air hingga ikan hiu bisa leluasa berenang di dalamnya, maka yang terjadi adalah sebaliknya, rubah dan manusia yang bisa bernapas dalam air, namun penggambaran elemen air tidak terlihat di sini.

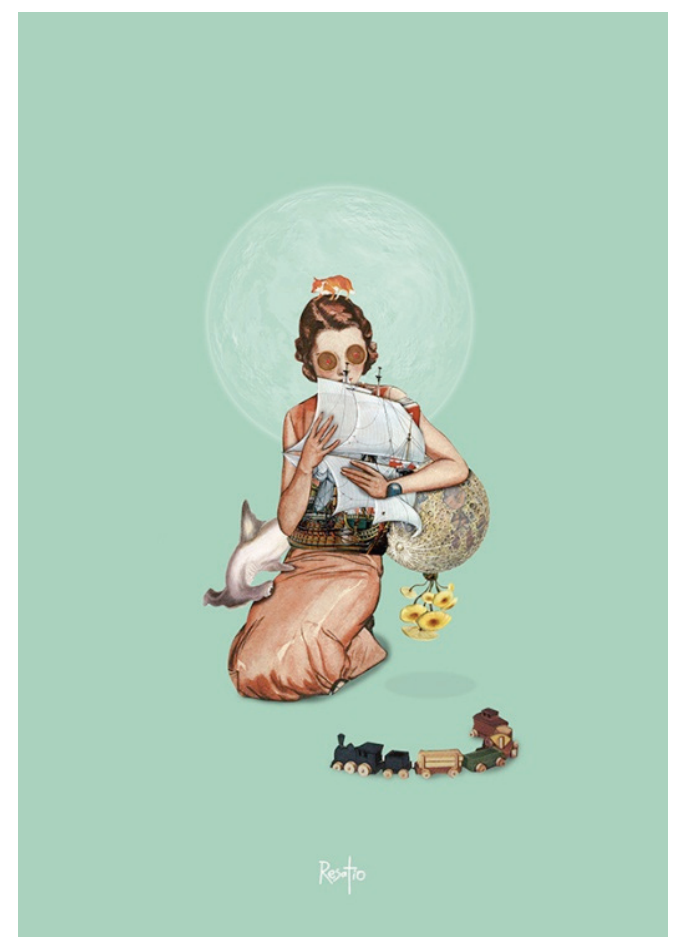

Gambar 6. An Odd Voyage

(Foto oleh: Novia Nur Kartikasari, 2015)

Selanjutnya bulan yang terletak di bawah lengan kiri wanita dijadikan penyangga seperti meja, ditumbuhi jamur ke arah bawah, seolah bulan memiliki unsur tanah yang dapat menjadi lahan bagi tetumbuhan untuk hidup, padahal keberadaan bulan dengan ukuran lebih kecil dan terletak di luar orbit saja sudah sangat menampakkan kejanggalan.

Rejuvenate, karya yang didominasi warna biru ini terdiri dari objek manusia, kepala rubah, ikan paus, kelinci, semacam bulan, kapal, dan jamur. Penggambaran mimpi tampak dalam Rejuvenate, suatu hal yang irasional seperti kelinci yang berada di bulan, kemudian ikan paus yang terbang seolah menarik manusia yang berada di bawahnya, walaupun binatang mamalia dan bernafas dengan paru-paru, bukan berarti paus bisa bertahan lama tanpa air. Dari segi ukuran tidak ada paus yang lebih kecil dari manusia, meski masih bayi atau baru lahir.

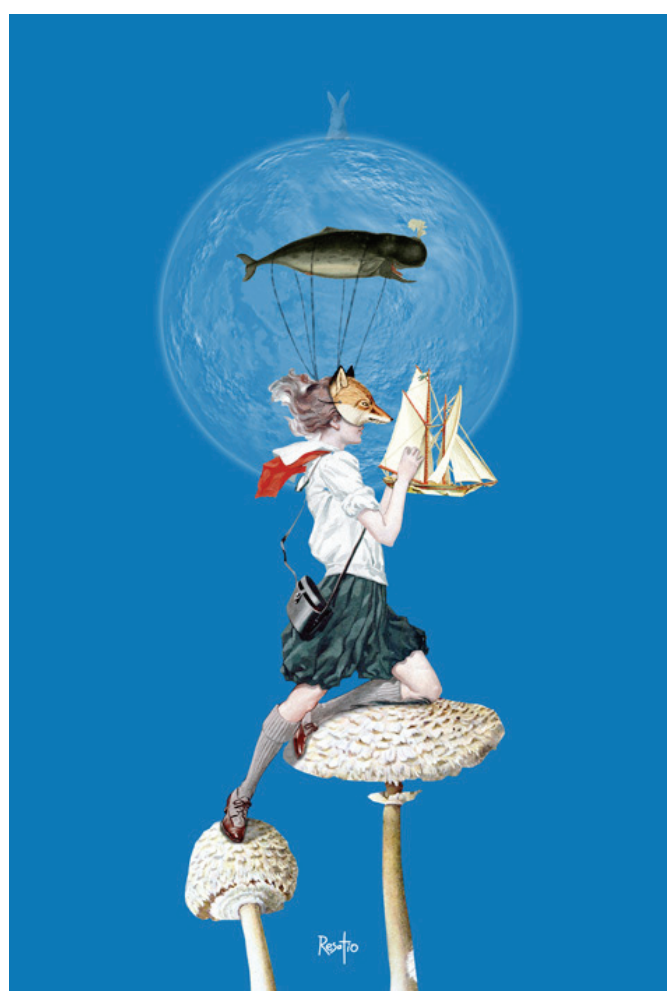

Gambar 7. Rejuvenate

(Foto oleh: Novia Nur Kartikasari, 2015)

Potongan kepala rubah yang seolah menjadi topeng manusia, menggabungkan dua hal tidak memiliki hubungan sama sekali, kemudian jamur yang menjadi tumpuan si gadis seolah merupakan benda yang kukuh, di dalam mimpi apapun yang tidak dapat terjadi dalam realitas akan menjadi wajar, realitas yang superior.

\section{Ciri Surealisme dalam Karya Resatio Adi Putra}

Surealisme tidak akan terlepas dari kata 'aneh', sesedikit apapun unsur itu dalam sebuah karya, maka kemungkinan untuk menyebut seniman penciptanya sebagai kaum surealis akan muncul, walau belum tentu murni surealis namun mencoba untuk menjadi surealis, dari penjelasan deskriptif mengenai berbagai ciri surealisme, tidak semua seniman membuat karya surealisme dengan memasukkan semua ciri tersebut, kembali kepada konsep, tujuan awal pembuatan karya, kedalaman pengalaman yang dimiliki oleh seniman, dan tidak lupa dan tidak akan terlewat adalah selera seniman. 
Surealisme, muncul dari berbagai pencampuran bentuk atau wujud tertentu yang berasal di luar nalar atau alam nirsadar, garis besar mengenai ciri surealisme antara lain dijelaskan dan dapat dipahami sebagai berikut:

"Apabila surealisme kita coba pahami secara lebih luas dan lugas sebagai gagasan estetik yang menjunjung tinggi fragmen-fragmen, koleksi-koleksi yang janggal (curio), serta penjajaran posisi yang tak-terduga; sebagai gagasan yang bekerja untuk menentang pengejawantahan realitas luar-biasa yang diambil dari wilayah-wilayah yang erotik, eksotik, dan tak sadar”. (Budiman, 2009: 36-37)

Keberadaan potongan-potongan sebuah objek, atau yang lebih familiar dengan sebutan fragmen, seringkali disebutkan ketika membahas mengenai surealisme. Fragmen-fragmen tersebut disejajarkan atau diletakkan bersamaan sebagai komposisi utuh dalam sebuah karya hingga memunculkan sebuah kejanggalan (curio). Fragmentasi inilah yang menjadi salah satu ciri khas surealisme, seperti yang ditemukan dalam setiap karya Resatio yang telah dianalisa sebelumnya, yang kebanyakan merupakan potongan tubuh manusia atau binatang.

Penyejajaran berbagai fragmen ini bukan sekedar disandingkan begitu saja, namun baru akan menjadi ciri surealisme ketika memunculkan kejanggalan, seperti yang tampak dalam karya Resatio yaitu manusia berkepala manusia, manusia berkepala tumbuhan, dan berbagai hal yang tidak dapat ditemukan dalam kehidupan sehari-hari. Kejanggalan yang merupakan ciri surealisme juga terlihat pada objek-objek seperti tulang belulang yang seolah hidup, binatang-binatang air yang dapat hidup di udara terbuka, ukuran binatang yang lebih kecil atau lebih besar dari pada wujud aslinya, ataupun penampakan ruang-ruang yang tidak dapat ditemukan dalam keseharian.

Karya yang surealis cenderung tidak akan menampilkan objek-objek yang secara harafiah hadir sebagai objek itu sendiri, seperti misalnya objek bunga maka tidak akan menggambarkan objek bunga yang sesungguhnya, namun bunga sebagai pengganti sesuatu yang (stand for) berdasar similaritas atau hubungan saling menggantikan antara objek lain dengan kemungkinan tak terbatas.

Munculnya kejanggalan diakibatkan oleh adanya hal tak terduga, seperti mimpi atau berasal dari alam tak-sadar, yang menciptakan visualisasi pengganti dari objek yang sesungguhnya, yang keberadaanya didasarkan pasa similaritas antar keduanya, maka objek tersebut menjadi sebuah ikon metaforik. Metafora merupakan ciri surealisme yang berikutnya, sebagai salah satu subjenis ikon, metafora muncul dari pengertian harafiah yang telah ditinggalkan dan digantikan oleh kiasan, memakai simbol sebagai pengertian utama dan mendapatkan konotasi sebagai tambahan (the literal sense has to be abandoned and tobe replaced by the figurative sense, the symbol retains its primary sense and acquires its connotation in addition) (Noth, 1990: 119)

\section{Ciri Surealisme dalam Karya}

Berdasarkan karya yang telah dianalisis, beberapa diantaranya menampilkan kesan yang menakutkan, mengerikan seperti tengkoraktengkorak yang seolah hidup, sejata atau benda tajam berlumuran darah, ataupun bola mata yang tidak dalam posisi yang sewajarnya. $\mathrm{Hal}$ semacam teror ini juga merupakan salah satu dari ciri surealisme, kemudian erotisme yang ditampilkan melalui beberapa sosok perempuan dengan pakaian minim atau badan yang tertutup kabut menjadi ciri surealisme yang berikutnya. Ciri-ciri surealisme muncul dalam karya Resatio dengan tidak bersamaan, dari beberapa ciri terkadang hanya muncul salah satu saja dalam sebuah karya, kadang lebih dari itu. Salah satu ciri yang muncul dalam sebuah karya belum tentu muncul kembali dalam karya yang lain, namun tetap dapat disebut sebagai karya surealis. Ciri tersebut adalah:

1. Munculnya kejanggalan (curio), yang berasal dari penggabungan berbagai macam fragmen dari objek-objek yang tidak memiliki keterkaitan sama sekali, atau semacam penyejajaran yang berbentuk metafora.

2. Munculnya dari berbagai hal yang berasal dari ketidaksadaran, atau berupa penampakan mimpi dan peristiwa yang 
tidak rasional, yang pada akhirnya juga menjadi sebuah kejanggalan karena tidak ditemukan dalam keseharian.

3. Terdapat objek-objek yang mengandung unsur erotisme, yang diwakilkan oleh sosok-sosok perempuan dengan pakaian minim mereka, atau badan yang setengah tertutup kabut.

4. Adanya penampakan sebuah teror, yang dapat dilihat dari objek-objek yang sekiranya dapat menimbulkan rasa takut dan ancaman.

\section{Otomatisme}

Salah satu hal yang kerap muncul dalam karya surealis adalah otomatisme (automatism), merupakan kreasi seni tanpa adanya kontrol kesadaran (the creation of art without conscious control) (Kleiner, 2009)(Kleiner, 2009:943) Hasil karya yang dibuat diluar kesadaran kadang terkesan berantakan, tidak teratur, karena pemilihan objek dan perpaduan komposisi yang spontan. Penerapan otomatisme dalam karya kolase, dilakukan dengan menggunting kemudian memadukan fragmen-fragmen tersebut dengan menempel tanpa direncanakan terlebih dahulu.

Satu poin yang tidak tampak dari semua karya Resatio yang telah dianalisis adalah unsur otomatisme. Otomatisme dalam melukis, terdapat proses yang menghasilkan dengan sendirinya berdasarkan pergerakan naluri dengan tangan setelah menentukan keadaan (seperti ukuran kertas atau media) dalam proses berkarya. (In painting, the process of yielding one self to instinctive motions of the hands after establishing a set of conditions (such as size of paper or medium) within which a work is to be created) (Kleiner, 2009:1031)

Berdasarkan yang terlihat dalam karya Resatio, bahwa komposisi, tatanan, maupun pemilihan objek sangat terencana, seolah terukur dengan presisi yang tepat, posisinya teratur. Otomatisme yang dimunculkan dalam karya surealis biasanya berwujud ketidakteraturan, karena prosesnya yang spontan, bukan tidak terkonsep, namun sebagian besar gagasan yang muncul mungkin terkesan tiba-tiba. Secara sederhana otomatisme juga bisa disebut sebagai suatu tindakan yang ekspresif, atau suatu hal yang spontan, mengalir sesuai dengan apa yang akan dilakukan seseorang tanpa harus berpikir terlebih dahulu.

Salah satu contoh seniman yang ketidakteraturan dalam karyanya mencerminkan adanya spontanitas yaitu Hannah Höch, bagaimana Höch memotong sebuah lembaran (misal foto saat membuat Photomontage) yang bergambar objek tertentu, terkesan tidak ada proses memotong yang disertai dengan pengukuran yang presisi bahkan terlihat asal (walau bukan berarti tanpa konsep), berikut dengan cara penyusunan objek. Sebagi contoh dalam karya berjudul 'Russiche Tanserin' (Russian Dancer), kejanggalan khas surealisme akan langsung nampak dalam karya Höch yang dibuat pada tahun 1928 tersebut.

Contoh yang lain adalah Joan Miro, pada salah satu lukisannya yang berjudul 'Carnival of Harlequin' (Eggener, 1993:36) susunan objek di dalamnya cenderung tidak beraturan, ditempatkan untuk memenuhi setiap sudut atau ruang dalam lukisan tersebut. Bentuk dari objek berbeda-beda bahkan jika tampak dari jenis yang sama, seperti ada dorongan ketidaksadaran hingga muncul bentuk atau komposisi yang tidak beraturan.

Berdasarkan rekaman wawancara Resatio Adi Putra saat penyelenggaraan pameran seni rupa Kopling \#5 ("https://www.youtube. com/watch?v=FHMXUrKqUMI,") saat ia menjerumuskan diri dalam dunia visual art, Resatio ingin membuat sebuah karya realis, namun karena merasa memilik keterbatasan menuangkan ide-idenya secara realis salah satu caranya dengan membuat kolase yang berasal dari gambar-gambar objek realis, yang digabungkan sedemikian rupa menjadi tidak realis lagi. Proses dalam ia berkarya tidak sembarang mengambil karya orang, tetapi sengaja mencari karya ilustrasi atau foto yang sudah sangat lama dan tak lagi bernama, lalu dalam penyusunan biasanya Resatio telah memilik cerita sebagai konsep dalam berkarya.

Susunan ataupun yang biasa disebut dengan komposisi objek dalam karya yang dikatakan cenderung berdasar pada prinsip otomatisme, berupa ketidakteraturan yang muncul berdasar dorongan alam nirsadar. Fragmen-fragmen 
yang digambungkan tanpa terencana, hingga memunculkan kejanggalan. Terlepas dari apakah karya yang diciptakan oleh Resatio Adi Putra menggunakan prinsip otomatisme atau tidak, karyanya dapat digolongkan sebagai pop art, kecenderungan memakai objek-objek yang juga sedang marak digunakan beberapa seniman kolase seperti objek manusia yang digabungkan dengan binatang maupun tumbuhan, beberapa seniman kolase itu di antaranya adalah Marcelo Monreal, seniman kolase asalh Brazil yang selalu menggabungkan fragmen wajah manusia dengan bunga-bunga, kemudian Karin JosephineChandra seniman kolase asal Jakarta yang cenderung memakai warna abu-abu pada karyanya, selain itu masih ada Deborah Kelly seorang seniman kolase asal Australia yang menggunakan objek perempuan sebagai dominasinya, serta masih banyak seniman kolase yang lain.

\section{Kesimpulan}

Visual Thief, yang merupakan artbook kumpulan karya Resatio yang menampilkan gambar sureal, menggunakan objek makhluk hidup seperti manusia ataupun binatang yang seringkali digunakan sebagai point of interest, tumbuhan ataupun benda-benda yang disusun kedalam sebuah komposisi dan menimbulkan kesan surealistik.

Konsep yang diusung Resatio dalam menciptakan karya mengenai pencurian yang diwakilkan oleh objek rubah, begitulah menurut perspektif seniman yang kemudian memunculkan objek rubah di berbagai karya, dan menjadikannya sebagai benang merah cerita dari sebagian besar karya yang diciptakan oleh Resatio Adi Putra. Mengenai genre karya Resatio yang konon menurutnya sendiri merupakan karya yang sureal seperti yang telah diutarakannya dalam setiap wawancara di media pemberitaan online, pada akhirnya menimbulkan pertanyaan apakah karya Resatio sungguh-sungguh sureal. Walaupun sebuah karya terkadang memiliki beberapa genre sekaligus, atau bahkan seniman kadang memberi nama untuk genre lukisannya sendiri, surealisme memiliki beberapa kriteria khusus. Ciri-ciri yang dapat membuat karya Resatio Adi Putra dapat Visual Thief dapat dikategorikan sebagai karya yang sureal adalah:
1. Munculnya kejanggalan (curio), yang berasal dari penggabungan berbagai macam fragmen dari objek-objek yang tidak memiliki keterkaitan sama sekali, atau semacam penyejajaran objek-objek yang berbentuk metafora.

2. Munculnya, penampakan mimpi dan peristiwa yang tidak rasional.

3. Terdapat objek-objek yang mengandung erotisme, seperti manusia (perempuan) yang memakai baju minim atau setengah telanjang.

4. Adanya penampakan sebuah teror, yang dapat dilihat dari objek-objek yang sekiranya dapat menimbulkan rasa takut dan ancaman.

Setidaknya ada minimal satu dari keseluruhan ciri surealisme yang dimiliki oleh karya Resatio, maka karya tersebut dapat disebut sebagai karya surealis. Namun ada satu hal yang tidak muncul dari semua karya Resatio yaitu otomatisme, merupakan teknik yang digunakan oleh para kaum surealis yang di dalamnya menggunakan dorongan alam pikiran bawah sadar sehingga tercipta karya yang nampak tidak teratur. Maka karya Resatio dapat dikatakan tidak sepenuhnya surealis, karena secara global, keteraturan yang ditampilkan Resatio sangat berbeda dengan konsep otomatisme. Penataan yang terencana, sangat presisi, sangat kecil kemungkinan merupakan hasil dari spontanitas. Surealis yang direncanakan, kemudian mencoba menjadikan karya surealis, hingga karya yang tercipta justru menjadi kurang surealis (less surrealism). Resatio menjadikan surealisme lebih sebagai sebuah style, daripada kecenderungannya sebagai sebuah movement.

\section{Daftar Pustaka}

Aspley, K. (2010). Historical Dictionary of Surrealism. Toronto: The Scarecrow Press.

Budiman, K. (2009). Sebuah Labirin untuk Garin. BULAK: Jurnal Sosial Dan Budaya Universitas Gadjah Mada., 3.

Eggener, K. L. (1993). An Amusing Lack of Logic: Surrealism and Popular

Entertainment. American Art, 7(4), 30-45. Fiddler, R. (2003). Mediamorfosis. Yogyakarta: 
Bentang Budaya.

Frances, M. (2009). "Collage and Cut-Ups the Art of Re-Arrangement." Personal Construct Theory \& Practice, 6(15), 22.

Freud, S. (1960). A General Introduction to Psikoanalisis. New York: Wasingthon Savare.

Hadler, M. (2011). "David Hare, Surrealism, and the Comics." The Space Between Brooklyn College and The Graduate Center., 7(1), 93-108.

Hofmann, I. E. (2001). Documents of Dada and Surrealism: Dada Surrealist Journals in the Mary Reynolds Collection. Chicago: The Art Institute of Chicago.

https://www.youtube.com/ watch?v=FHMXUrKqUMI. (n.d.).

Kleiner, F. S. (2009). Gardner's Art Throught the Ages: A Global History (13rd edition). USA: Thomson Wadsworth.

Lash, S. (2012). Sosiologi Postmodernisme. Yogyakarta: Kanisius.

Mc. Neese, T. (2006). Salvador Dali: The Great Hispanic Heritage. . USA: Infobase Publishing.

Noth, W. (1990). Handbook of Semiotic. Blomingtoon \& Indianapolis: Indiana University Press. 1990.

Pooke, G., \& Newall, D. (2008). Art History: The Basics. London \& New York: Routledge. Warlick, M. E. (2001). Max Ernst and Alchemy: A Magician in Search of Myth. Austin: University of Texas Press. 